\title{
THE PROMISED CONSTITUTION OF THE PROMISED LAND: THE ISRAELI CONSTITUTIONAL EXPERIENCE
}

\section{Z. Sigal \& A. S. Rehany ${ }^{* *}$}

Recently many distinguished commentators have expressed the need for a formal and written constitution in the United Kingdom. ${ }^{1}$ The intention of this article is not to discuss the requirement of such a constitution, but rather to offer a general outline of the development of the Israeli constitution. However, the British lawyer might find the Israeli model useful as a stimulant of new ideas for constitutional reform.

In reading this article, several questions should be kept in mind. The first is the frequently discussed issue of whether there is a need for a written constitution. ${ }^{2}$ The second part of the article, which discusses the establishment of the State of Israel, its Declaration of Independence and the decision to adopt a piecemeal constitution, might suggest that the answer to this question is not necessarily in the affirmative.

Secondly, if one is advocating a written constitution for the U.K., one should ask how such constitution should be introduced to a state with a long-standing tradition of a non-written constitution. To this the third part, which portrays the birth of the Israeli Constitution, i.e. the enactment of the various Basic Laws, is relevant.

Finally, one should be aware of the rôle that political interests, on the one

" Of Oxford Brookes University.

"* Formerly Member of Trinity College, Oxford. The authors wish to thank Dr.Rachael Craufurd Smith and Mr.Adam Samuel for their remarks on an earlier draft of this article.

${ }^{1}$ De Smith \& Brazier, Constitutional \& Administrative Law (7th.ed.,Penguin, 1994) at 48; Lord Denning, What Next in the Law (Butterworth, 1982) at 319; Jowell \& Oliver (eds.) The Changing Constitution (3rd.ed., Clarendon, 1994).

${ }^{2}$ Lord Browne-Wilkinson, "The Infiltration of A Bill Of Rights" [1992] P.L. 405. 


\section{DENNING LAW JOURNAL}

hand, and judicial activism on the other, play in the formation of a written constitution. These will become apparent in the fourth part where two recent Basic Laws which directly concern fundamental rights are discussed.

As background the first part of the article outlines the legal sources of Israeli law which date back to the period before the establishment of the State of Israel.

\section{Before the Establishment of the State of Israel 1517-1948}

Palestine was under Ottoman rule from 1517 until the end of the First World War. It was conquered by the British troops in 1917, and was granted to England in 1922 by the League of Nations as a Mandatory Territory for the purpose of establishing "a national home for the Jewish People." Thus, thirty years of British mandate over Palestine began. ${ }^{3}$

The British administration found the Ottoman law, under which Palestine was governed difficult to apply to modern legal problems. This lead to a steady process of modification of the Ottoman legal system during the period of the British mandate. The modification of the Ottoman legal system was conducted by the British in various forms.

The first was by introducing statutes based upon Westminister legislation ${ }^{4}$ or by issuing ordinances which gave statutory form to existing British common law principles. The second was by virtue of Article 46 of an Order-in-Council from 1922. ${ }^{5}$ In case of a lacuna in the local laws, this Article provided that the mandate administration would apply the British common law rules and the doctrines of equity which were in force at that time in England. As the vast majority of the judiciary in Palestine was British, Article 46 was given a wide interpretation in order to give English Law a greater foothold within the laws of Palestine. At the end of the mandate period, in 1948, Palestinian law had become dominated by English law, with only residual elements of Ottoman principles. ${ }^{6}$

${ }^{3}$ D.Friedman, "The Infusion of Common Law into the State of Israel" (1975) 10 Israel.L.Rev. 324.

${ }^{4} \mathrm{Eg}$. the Bills of Exchange Act 1882 and the Companies Act 1929.

${ }^{5}$ Palestine Order in Council, 10th.August, 1922.

${ }^{6}$ D.Friedmann, "The Effect of Foreign Law on the Law of Israel: Remnants of the Ottoman Period" (1975) 10 Israel.L.Rev. 192. 


\section{THE PROMISED CONSTITUTION OF THE PROMISED LAND}

\section{Between the Establishment of the State of Israel and the Enactment of the First Chapter of the Constitution 1948-1958}

From the very first day of the existence of the state of Israel it was obvious that the new state would follow many other modern western states in having a formal constitution. The requirement for a formal constitution and for the establishment of a Constituent Assembly are clearly stated in the Declaration of the Establishment of the State of Israel. ${ }^{7}$

The rôle of the executive was to be performed by a Provisional Council and the task of adopting a constitution was to be performed by the Constituent Assembly. The co-existence of the Provisional Council and the Constituent Assembly was terminated by the Constituent Assembly (transition) Ordinance. Thus, the task of adopting a formal constitution was to be performed by a constitutional body which consisted of both a Constituent Assembly and a House of Representatives. That body later transformed into the first Knesset (the Israeli Parliament).

On its first anniversary a debate was held in the Knesset on the issue of whether or not a written constitution should be adopted. ${ }^{9}$ For the purpose of this discussion a description of the political parties which participated in that debate is irrelevant, as are the parliamentary relations between these parties. Arguments for and against a written constitution were generally similar to those often made

${ }^{7} 1948$ 1 L.S.I. 4 (1948): "We declare that with effect from the moment of the termination of the [British] Mandate, being tonight, the eve of Sabbath, the 6th.of Iyar, 5708 [15th.May, 1948], until the establishment of the elected, regular authorities of the State in accordance with the constitution which shall be adopted by the elected Constituent Assembly not later than Ist.October, 1948, the people's Council shall act as Provisional Council of State, and its executive organ, the people's Administration, shall be the Provisional Government of the Jewish State, to be called the State of Israel" (emphasis added).

${ }^{8} 19492$ L.S.I. 81 (1948/49) s.3: "The Constituent Assembly shall, so long as it does not itself otherwise decide, have all the powers vested by law in the Provisional Council of State." Also see s. 1: "The Provisional Council of State shall continue in office until the convening of the Constituent Assembly of the State of Israel; upon the convening of the Constituent Assembly, the Provisional Council of State shall dissolve and cease to exist."

${ }^{9}$ Divrei Ha-Knesset [the Israeli equivalent of the British Hansard] (1950) vol.IV, 714 (in Hebrew). For a summary of that debate in English see, Emanuel Rackman, Israel's Emerging Constitution (Columbia University Press, New York, 1955) at 110-117. 


\section{DENNING LAW JOURNAL}

with regard to a British Constitution. ${ }^{10}$

However, some of the arguments which were particular to Israel are noteworthy. Such arguments which supported a written constitution were: first, that both The Declaration of the Establishment of the State of Israel ${ }^{11}$ and the United Nations General Assembly resolution ${ }^{12}$ called for a written constitution. Secondly, a constitution would have an important educational value. This was thought to be of special significance due to the flood of Jewish immigrants from different socio-legal backgrounds. ${ }^{13}$ Thirdly, a written constitution would embody declarations of fundamental freedoms, thus contributing to the democratic values of the new State. ${ }^{14}$

These arguments seem to rely upon the particular political and socio-economic situation of the new state. Ironically, those opposing a written constitution relied upon the very same political and socio-economic circumstances: first, to create rigid and unchangeable laws, without first testing their application, could lead to disastrous results. ${ }^{15}$ Secondly, it would be useless to create a written constitution at this point in the history of the Jewish state. Only after the historic process had taken place could the constitutional form of the State be included within a written constitution. ${ }^{16}$ Thirdly, even the drafting of the constitution would lead to a severe dispute within the people as to what the constitution should include. This dispute existed, and still exists today, between the religious parties who oppose a written constitution, and the secular parties, the majority of which favour a written constitution. ${ }^{17}$ Fourthly, the constitution should be adopted only

${ }^{10}$ See e.g. Antoine Clarke, "The Case for a Written Constitution: Even Broken or Bad Promises are Better in Writing" Liberation Alliance No.4 (1996), \& Lord Browne-Wilkinson, supra.n.2.

${ }^{11}$ Supra.n.6.

${ }^{12}$ G.A.Res.133 U.N.Doc.A/519 at 131-50 (1947). This Resolution dealt with the partition of Palestine into a Jewish State and an Arab State. Both projected States were to have a formal constitution.

${ }^{13}$ Divrei Ha-Knesset (1950) vol.IV 734.

${ }^{14}$ Ibid. at $736,737,745 \& 824$.

${ }^{15}$ Ibid. at 727.

${ }^{16}$ Ibid at 732 .

${ }^{17} \mathrm{Ibid}$ at 812 . 


\section{THE PROMISED CONSTITUTION OF THE PROMISED LAND}

after the majority of the Jewish people gathered in the new State. Any other course of action would lead to a constitution which would reflect the will of a minority of the people. ${ }^{18}$

Towards the end of the debate, two resolutions were proposed as possible settlements of the dispute. The first was called the resolution of the 37 (Members of Knesset); the second was called the Harrari resolution since it was proposed by Mr.Yizhar Harrari M.K. (Member of Knesset). ${ }^{19}$ Due to political and paramilitary reasons the Harrari resolution was adopted by the Knesset. Thus, the Israeli constitution was to be formed in a piecemeal manner, each chapter of the piecemeal constitution to be called a Basic Law. However, the constitutional status of these Basic Laws was not clear from the wording of the Harrari resolution, and it remained to be seen what status would be given to them.

The first Basic Law to be passed was Basic Law: The Knesset ${ }^{20}$ in $1958 .{ }^{21}$ The period of eight years between the Harrari Resolution and the passing of Basic Law: The Knesset, created a constitutional vacuum. It was clear from the Harrari resolution that some chapters of the Israeli constitution should be made. In the absence of such laws the Israeli judicial system referred to other constitutional sources, such as the Declaration of the Establishment of the State of Israel.

The Declaration of the Establishment of the State of Israel states that:

"It will be based on freedom, justice and peace as envisaged by the prophets of Israel; it will ensure complete equality of social and

\section{${ }^{18}$ Ibid.at 819.}

${ }^{19}$ Divrei Ha-Knesset (1950) vol.V, 1743 (in Hebrew). The first proposition read: "The Knesset decides to charge the Constitutional, Legislative and Judicial Committee with the preparation of the State constitution, and to present it to the first Knesset. The Knesset will decide upon the dates of the termination of the committee's work" [emphasis added]. The second proposition read: "The first Knesset charges the Constitutional, Legislative and Judicial Committee to prepare a proposed constitution for the State. The constitution shall be constructed in chapters in such a way that each of them shall be a fundamental [sometimes referred to as 'Basic Laws'] law by itself. The chapters shall be brought before the Knesset as the committee finishes its work on each, and all the chapters together shall then be combined into a constitution for the State." From the different wording it is obvious that the latter, unlike the former, is an indefinite postponement of the formation of a formal constitution. This is, most likely, the reason that the latter was adopted, for it served the interests of those who opposed the constitution.

${ }^{20}$ A colon is used to indicate that the words "Basic Laws" are not an integral part of the name of the Act.

${ }^{21} 195812$ L.S.I. 85 (1958). See also Amendment no. 313 L.S.I 228 (1958). 


\section{DENNING LAW JOURNAL}

political rights to all its inhabitants irrespective of religion, race or sex; it will guarantee freedom of religion, conscience, language, education and culture..."22

In the landmark case of Kol Ha'am v.The Minister of Interior ${ }^{23}$ the Minister of Interior ordered the suspension of the publication of the newspaper of the Communist party called ' $\mathrm{Kol} \mathrm{Ha}$ 'am (the English translation is "the voice of the people'). Under the Press (amendment) Ordinance $1936{ }^{24}$ section 19(2)(a), the Minister of Interior had the right to do so if he was of the opinion that the publishing of the newspaper was "likely to endanger the public peace..." ${ }^{25}$ The newspaper sought a cancellation of the Minister's order, contending that it impaired the freedom of expression and of the press. The result of the case depended on the construction of the word 'likely' in section 19(2)(a). There were two possible interpretations. The first is that 'likely' is to be construed as meaning 'probable' thus giving the section a narrow scope of application. The second is that 'likely' is to be construed as meaning 'bare tendency,' thus giving the section a wider scope.

The Israeli Supreme Court preferred the former. In stating the ratio decidendi, reference was made to the clause in the Declaration of the Establishment of the State of Israel which was quoted above. Great importance was attached to the clause as an interpretative tool as it had been stated to be an "aspiration of the people and their basic credo." ${ }^{26}$ This was the reason for the court's decision to restrict as much as possible the interference of the executive with the principles of freedom as they were set out in the Declaration of the Establishment of the State of Israel.

Some commentators have referred to the decision in $\mathrm{Kol} \mathrm{Ha}$ 'am as creating a "soft legal principle." ${ }^{27}$ In the opinion of Professor D. Kretzmer ${ }^{28}$ these

221948 1 L.S.I. 4 (1948).

${ }^{23}$ H.C. $73 / 53$ (1953) 7 P.D.871.

${ }^{24}$ The Palestine Gazette 1937 sup. 113.

${ }^{25}$ Ibid.

${ }^{26}$ H.C. 10/48, Zee v. Gubernik (1948) 1 P.D.85 at 89.

${ }^{27}$ D.Kretzmer, "Demonstrations and the Law" (1984) 19 Israel L.Rev. 47 at 64.

${ }^{28}$ Of the Hebrew University of Jerusalem, $i b i d$. 


\section{THE PROMISED CONSTITUTION OF THE PROMISED LAND}

principles are legal because in the absence of express statutory authority, the executive is bound to act according to these principles. However, these principles are 'soft' because they do not interfere with the doctrine of the supremacy of Parliament. The Knesset can at any time pass a statute which will restrict these principles. Such a statute will not be subjected to judicial review even if it will interfere with these legal principles. ${ }^{29}$

\section{The Enactment of Basic Laws 1958-Present day}

The next stage in the development of the Israeli constitution was the enactment of Basic Laws of which some provisions are entrenched. Thus, for example, sections $4^{30}$ and $44^{31}$ of Basic Law: The Knesset are entrenched in various degrees by requiring special majorities in the Knesset for any change of these sections. It remained to be seen whether the courts would review subsequent legislation in the light of the entrenched sections of the new Basic Law.

It took eleven years before the courts were confronted with the problem of reviewing legislation subsequent to Basic Law: The Knesset. In 1969 Mr. A. Bergman $^{32}$ submitted a petition to the Israeli High Court of Justice contending that the financing law for the next elections ${ }^{33}$ was contrary to section 4 of the Basic Law: The Knesset.

The section read: "The Knesset shall be elected by general, national, direct, equal, secret and proportional elections, in accordance with the Knesset Elections Law; this section shall not be varied save by a majority of the members of the Knesset." ${ }^{34}$ Mr. Bergman contended that the new finance law was disadvantageous to new lists running for the Knesset, since it allowed public financial aid only to parties which were represented in the outgoing Knesset. This contradicted the requirement that the elections shall be equal, as stated in

${ }^{29}$ C.A. $450 / 70$ Regozinsky v. State of Israel (1972) 26(1) P.D. 129.

${ }^{30} 195812$ L.S.I. 85 (1958).

${ }^{31} 195812$ L.S.I. 89 (1958).

${ }^{32}$ H.C. 231/73 Aharon A.Bergman v. The Minister of Finance \& Comptroller (1969) 23(1) P.D.693. For an English translation see (1969) 4 Israel.L.Rev. 559.

${ }^{33}$ Which were to be held in the same year (Elections to the Knesset and Local Authorities in the year 5730 (Financing, Limitation of Expenses and Auditing) Law, 5729-1969.

${ }^{34} 195812$ L.S.I. 85 (1958) (emphasis added). 


\section{DENNING LAW JOURNAL}

section 4 of Basic Law: The Knesset.

Mr. Bergman also contended that the new finance law had not received a majority of the votes in the Knesset and therefore was illegal. The Supreme Court upheld the claim of Mr. Bergman, thus exercising judicial review of legislation which is not consistent with the entrenched section of Basic Law: The Knesset.

The decision of the Supreme Court paved the way for other similar decisions which followed ${ }^{35}$ - most of which dealt with section 4 of Basic Law: The Knesset.

The results of the Bergman case were threefold. First, it had established, as mentioned, the judicial review of statutes within the context of a contradiction between statutes and entrenched sections of Basic Laws. Secondly, it had qualified the doctrine of the supremacy of the Knesset. It'was clear after the Bergman case that the Knesset can bind itself. Thirdly, due to the results of the Bergman case the government had approved the drafts of two Basic Laws which, if enacted, would formally make all Basic Laws superior to all other legislation. ${ }^{36}$ These Basic Laws are: Basic Law: Legislation ${ }^{37}$ and Basic Law: The Courts. ${ }^{38}$

The soft legal principles which were the outcome of Kol Ha'am could be seen as "islands" of a written constitution within a system without such a constitution. The entrenched provisions of the various Basic Laws and the effect of Bergman, constitute such "islands" which are not as "soft" as the previous ones.

On 3rd.March, 1992 a "continent," rather than an "island" emerged. That "continent" was Basic Law: Freedom of Occupation. The purpose of this Basic Law is to ensure that the freedom of occupation of every citizen or inhabitant of the state will not be restricted, unless for a worthy purpose and to the benefit of

${ }^{35}$ E.g. H.C. 246/81 Derech Eretz v.Broadcasting Authority (1981) 35(4) P.D.1.

${ }^{36}$ At the present time they are still not enacted.

${ }^{37}$ Section 11 of the draft reads: "A law which amends a Basic Law, whether expressly or by implication, or which contradicts the provisions of the Basic Law, is adopted when a majority of the members of the Knesset votes in its favour at the final reading, unless there is a contrary provision in this regard contained in a Basic Law." Section 12(a) reads: "No objections shall be raised with regard to the validity of a law except where such an objection claims that the law amends a Basic Law, or that the recorded number of Knesset Members voting in its favour did not constitute an adequate majority."

${ }^{38}$ Section 15(a) of the draft reads: "The Supreme Court, sitting as the Constitutional Court, will consider objections claiming that a law amending a Basic Law, did not receive the required majority; the procedure will be set out in the Civil Procedure Rules." 


\section{THE PROMISED CONSTITUTION OF THE PROMISED LAND}

the majority. The section which is the most relevant to this discussion, and which has made the greatest contribution to the development of the Israeli Constitution is section 5 of the Basic Law which reads: "This Basic Law may not be changed except by a Basic Law enacted by a majority of the Members of the Knesset. ${ }^{.39}$

The contribution of this section to the development of the Constitution is twofold. First, it does not entrench either a single or a number of provisions of a Basic Law as does section 4 or 44 of Basic Law: The Knesset. Section 5 of Basic Law: Freedom of Occupation entrenches the whole of this Basic Law. This actually grants this Basic Law a status of a semi-formal constitution. Due to the Bergman precedent, any other legislation which is in either express or implied contradiction with this Basic Law, will be subjected to judicial review. However, it is a status of a semi-formal constitution because contradicting subsequent legislation will be subjected to judicial review only within the context of the manner in which it was enacted. There is no provision for judicial review of such legislation purely on the basis of a substantive contradiction with the Basic Law.

Secondly, unlike other types of entrenchment of provisions of Basic Laws, this entrenchment is not made by requiring a special majority but rather by requiring the enactment of another Basic Law. This method of entrenchment is even more rigid than any requirement of a special majority. However, the effect of this Basic Law as well as the content of another Basic Law, namely, Basic Law: Human Dignity and Liberty, were significantly diminished by political influence, mainly the political interest of the religious parties.

\section{An Emerging Bill of Rights?}

Until 1992, none of the Basic Laws dealt with fundamental human rights. The reason for this is the opposition of the religious parties to a Bill of Rights (this was also the primary objection to the adoption of a written constitution). The religious parties oppose a Bill of Rights because it will entail judicial review of statutes which were enacted due to the Parliamentary power of the religious parties. A significant portion of these statutes are inconsistent with fundamental freedoms and rights, due to their religious nature. Thus, should judicial review be exercised over them, they might be rendered illegal.

In 1992, two Basic Laws concerning fundamental rights were enacted: Basic Law: Freedom of Occupation, and Basic Law: Human Dignity and Liberty. With regard to these two Basic Laws, two points should be especially noted. The first

\footnotetext{
${ }^{39}$ Translation by the authors
} 


\section{DENNING LAW JOURNAL}

is that the content of the latter and the entrenchment of both the Basic Laws, were significantly influenced by political interests. The second is that the effect of these political interests was balanced by the judicial activism of the Supreme Court of Israel.

As mentioned above the first version of the Basic Law: Freedom of Occupation, was entrenched as a whole. This was because it was assumed that the issues with which this Basic Law deals were not controversial within the religious-secular debate. It was not too long before it became apparent that the Basic Law: Freedom of Occupation does have an affect over religious oriented laws.

In Meatrael Ltd. v. Ministry of Commerce and Industry, ${ }^{40}$ the Supreme Court decided that restrictions on meat importations on the basis that the meat does not comply with dietary religious (Kosher) Jewish laws, ${ }^{41}$ were in violation of Basic Law: Freedom of Occupation.

The judgement sparked a political debate which resulted in a political deal under which the Basic Law is to be re-enacted. Section 8 of the new version of the Basic Law retains the power of the Knesset to enact laws contrary to Basic Law: Freedom of Occupation provided that it was enacted by an absolute majority, and secondly, that it is expressly stated that it is enacted notwithstanding the rights protected by the Basic Law. A statute enacted by virtue of this overriding clause shall automatically expire four years after it came into force. ${ }^{42}$ Once this overriding clause was introduced into the new Basic Law, the Knesset enacted the Import of Frozen Meat Law 1994 which prohibits the import of non-kosher meat into Israel.

The religious-secular debate is probably the reason for the lack of entrenchment of Basic Law: Human Dignity and Liberty. As this Basic Law was clearly concerned with more controversial issues, it was not entrenched as a whole as was Basic Law: Freedom of Occupation. Moreover, the rights protected by Basic Law: Human Dignity and Liberty are far from similar to parallel provisions in other human rights declarations and treaties, such as the European Convention of Human Rights and the Universal Declaration of Human Rights.

The fundamental rights which the Basic Law includes are: the right to life, body, dignity, property, liberty of the individual, the right to leave and enter the

${ }^{40}$ H.C. $5871 / 92$ (1993) 47(1) P.D.521.

${ }^{41}$ These were mainly against the importation of pork.

${ }^{42}$ This is similar to $\mathrm{s} .33$ of the Canadian Charter of Rights and Freedoms. 


\section{THE PROMISED CONSTITUTION OF THE PROMISED LAND}

country, and the right to privacy and personal confidentiality. It is evident that fundamental rights such as freedom of religion and sexual equality were not protected by the Basic Law due to political pressure exerted by the religious parties.

Nonetheless, the Supreme Court, in taking an active stance, mitigated both the lack of entrenchment and the lack of protection of such rights. The lack of protection of various fundamental rights by the Basic Law was remedied in $E l-A l$ Air Lines v. Danilewitz. ${ }^{43}$ This was done by including under the general term "Human Dignity" rights such as equality and freedom of expression. Thus, the Supreme Court held that benefits to which spouses of El-Al employees are entitled should also be given to the homosexual partner of an El-Al air attendant.

The lack of entrenchment of Basic Law: Human Dignity and Liberty was remedied by a bench of nine judges in late 1995. In United Kizrachi Bank Ltd. v. Migdal Co.Op.Village most of the judges dealt with this question directly. ${ }^{44}$ The majority held that both Basic Law: Human Dignity and Liberty and Basic Law: Freedom of Occupation have the status of a formal constitution and are, therefore, superior to ordinary legislation. As a result, the courts have the power to review such legislation and to determine whether it is illegal on the basis that it is inconsistent with the Basic Laws.

The effect of this judgement is that all Basic Laws seem to enjoy the status of a formal constitution, irrespective of whether they are entrenched in whole or in part. This is a very dramatic decision, because the Knesset never expressly stated that the Basic Laws ought to have such a status at this stage in the development of the Israeli Constitution.

At the present time this is the current status of the emerging Israeli constitution. In addition to the aforementioned Basic Laws, the following Basic Laws have been enacted: Basic Law: Israel Lands 1960; Basic Law: The President of the State 1964; Basic Law: The Government 1968; Basic Law: the State Economy 1975; Basic Law: The Army 1976; Basic Law: Jerusalem, Capital of Israel, 1980; Basic Law: Judicature 1984; and Basic Law: The State Comptroller 1988.

One can humbly predict that two factors will contribute to the further development of the Israeli Constitution. The first is the enactment of the drafts of Basic Law: Legislation, and Basic Law: The Courts. Such an enactment will actually be the establishment of the formal constitution of the State of Israel. The

\footnotetext{
${ }^{43}$ H.C. $1107 / 94$ (1994) not yet reported.

${ }^{44}$ C.A.6821/93 (1995) 49(4) P.D. 221.
} 


\section{DENNING LAW JOURNAL}

second factor is not as dramatic as the first one but not less significant. It is the recent appointment of Justice Barak, a man known for his activist approach, to the position of the President of the Israeli Supreme Court of Justice.

\section{Conclusion}

In summary, the State of Israel was envisaged as a democratic state with a written constitution. This is apparent from the Declaration of the Establishment of the State of Israel. However, due to political reasons, the formation of such a constitution was postponed indefinitely. Instead, a compromise between those who favour and those who oppose a written constitution was reached. Under the famous Harrari resolution, the constitution was to be adopted in a piecemeal fashion. Each "chapter" of the constitution dealt with different aspects of the constitutional order of the state. Before the enactment of any such chapters, the Supreme Court had demonstrated that it would enforce constitutional values, even in the absence of a written constitution, or part thereof.

Once Basic Laws were enacted, their constitutional status was left uncertain. Some were entrenched in part, and others were entrenched as a whole. The content, as well as the degree of entrenchment of these Basic Laws, were significantly influenced by the religious - secular debate which has been going on in Israel since the very first day of its existence. What seems to be balancing these effects is the activist approach of the Israeli Supreme Court which recently stated that Basic Law: Freedom of Occupation, and Basic Law: Human Dignity and Liberty have the status of a formal constitution and therefore renders subsequent legislation susceptible to judicial review.

What remains to be seen is whether this activist approach will be applied to other Basic Laws, and whether the Knesset will take the necessary steps for creating a written constitution in Israel. Namely the enactment of Basic Law: Legislation, and Basic Law: The Courts. 